Hydrol. Earth Syst. Sci., 17, 211-223, 2013

www.hydrol-earth-syst-sci.net/17/211/2013/

doi:10.5194/hess-17-211-2013

(C) Author(s) 2013. CC Attribution 3.0 License.

\title{
Streamflow response of a small forested catchment on different timescales
}

\section{A. Zabaleta and I. Antigüedad}

Hydrogeology and Environment Group, Science and Technology Faculty, University of the Basque Country, 48940 Leioa, Basque Country, Spain

Correspondence to: A. Zabaleta (ane.zabaleta@ehu.es)

Received: 26 July 2012 - Published in Hydrol. Earth Syst. Sci. Discuss.: 6 August 2012

Revised: 14 December 2012 - Accepted: 19 December 2012 - Published: 22 January 2013

\begin{abstract}
The hydrological response of a catchment to rainfall on different timescales is result of a complex system involving a range of physical processes which may operate simultaneously and have different spatial and temporal influences. This paper presents the analysis of streamflow response of a small humid-temperate catchment (Aixola, $4.8 \mathrm{~km}^{2}$ ) in the Basque Country on different timescales and discusses the role of the controlling factors. Firstly, daily time series analysis was used to establish a hypothesis on the general functioning of the catchment through the relationship between precipitation and discharge on an annual and multiannual scale (2003-2008). Second, rainfall-runoff relationships and relationships among several hydrological variables, including catchment antecedent conditions, were explored at the event scale (222 events) to check and improve the hypothesis. Finally, the evolution of electrical conductivity (EC) during some of the monitored storm events (28 events) was examined to identify the time origin of waters. Quick response of the catchment to almost all the rainfall events as well as a considerable regulation capacity was deduced from the correlation and spectral analyses. These results agree with runoff event scale data analysis; however, the event analysis revealed the non-linearity of the system, as antecedent conditions play a significant role in this catchment. Further, analysis at the event scale made possible to clarify factors controlling (precipitation, precipitation intensity and initial discharge) the different aspects of the runoff response (runoff coefficient and discharge increase) for this catchment. Finally, the evolution of EC of the waters enabled the time origin (event or pre-event waters) of the quickflow to be established; specifically, the conductivity
\end{abstract}

showed that pre-event waters usually represent a high percentage of the total discharge during runoff peaks. The importance of soil waters in the catchment is being studied more deeply.

\section{Introduction}

Catchments are dynamic and complex systems involving a range of physical processes (natural or anthropogenic) which may operate simultaneously and have different spatial and temporal influences. The natural hydrological systems are characterized by tremendous variability in space, time and process (Kirnbauer et al., 2005) and the hydrological response (hydrograph) of a catchment to rainfall on different timescales is the result of this complex system. Understanding those processes is essential for managing the quality and quantity of runoff, especially when environmental conditions (climate or land use) are changing (Naef et al., 2002; Negley and Eshleman, 2006; Stewart and Fahey, 2010).

The input in a catchment (rainfall) is modulated by the interaction of different processes which vary with climate and catchment properties. Consequently, the general hydrological functioning of a catchment can be deduced from studies of the overall runoff response at the outlet of the system. This overall response is often used to estimate hydrodynamic parameters and to quantify the relative importance of the different flow components. Correlation and spectral analysis of time series has been widely applied with this aim. This type of analysis was initially developed 
by Jenkins and Watts (1968) and Hanna (1970), among others, and more recently it has been employed by many authors. Mangin (1981a, b) was one of the first authors to propose correlation and spectral analysis of temporal series of discharge in hydrological studies. These techniques have been widely used in karst hydrogeology in general (Mangin, 1984; Padilla and Pulido-Bosch, 1995; Mathevet et al., 2004) and also in the Basque Country in particular (Antigüedad, 1997).

Though time series analysis has mainly been applied to series obtained in karst aquifer systems, some authors have applied this methodology to other environments. Lee and Lee (2000) used correlations between hydrological time series data to characterize the hydrogeological processes of a fractured, igneous bedrock aquifer system in Korea. Jo and Lee (2010) analysed the hydrological time series data (water level, temperature, electrical conductivity) obtained from an underground liquefied petroleum gas storage cavern to understand its hydrogeological conditions. In the literature, some references, although not many, can also be found using of this type of analysis in river catchments. For example, Molénat et al. (1999) tried to identify hydrological processes operating in agricultural catchments by comparing observed transfer functions (associated with the cross-correlogram calculated from precipitation and discharge data) to simulated ones. Efstathios and Abiose (1974) and more recently Bouanani et al. (2005) have tried to understand the functioning of hydrological systems by means of correlation and spectral analysis in river basins of New Jersey and Algeria, respectively. Efstathios and Abiose (1974) observed a highly nonlinear relationship between rainfall and runoff in two river basins by employing cross-correlation and cross-spectral analyses. Bouanani et al. (2005) evaluated the hydrological response of three catchments, one more karstic in nature than the others, evidencing that time series analysis can be useful for comparison purposes.

Correlation and spectral analysis has also been used to identify the working mechanisms of the systems investigated through the description of the chronological series and their structures. Despite the value of this type of method being recognized, there are some aspects of the analysis that need to be taken into account to avoid errors in the interpretation and generalization of results. In particular, the results obtained from time series analysis depend not only on the inherent characteristics of the system but also on the temporal distribution of recharge (input). According to Eisenlohr et al. (1997), the form of the correlograms depends on several factors besides the structure of the system. The frequency of rainfall events is one of those factors; the more frequent the rainfall events, the more rapid the decrease in the runoff autocorrelogram. In relation to this, Grasso (1998) shows that the transfer function (cross-correlogram) cannot really be considered a characteristic of a given system because the results of the analysis are so strongly influenced by the frequency of the input events.
However, as Jeannin and Sauter (1998) stated, this method is a useful tool for identifying some overall characteristics (mainly cyclical variations) of time series, which are possibly not visible on a standard hydrograph. The results obtained by these methods can be used for constructing hypotheses, but then these should be verified by other methods such as direct observations on different timescales.

Another source of information on the hydrological functioning of a catchment is rainfall-runoff relationships at the event scale. The hydrological response of a catchment during a rainfall event depends on the combination of many different factors related to properties of the catchment, characteristics of the rainfall and initial conditions. These factors determine the active processes taking place during rainfall-runoff events and the interaction between them. Hence, the storm hydrograph is the result of the combination of the different processes taking place in the catchment over time. In line with this, many studies in different environments have demonstrated the complexity and evident non-linearity of rainfall-runoff relationships (Hewlet and Hibbert, 1967; Jordan, 1992; Latron, 2003).

In particular, many authors have noted the importance of subsurface flow and catchment wetness in hydrological processes and their magnitude, and in many studies analyses of rainfall, discharge and antecedent conditions have been combined to assess the influence of catchment wetness on hydrological response (e.g., Abdul and Gillham, 1989; Price, 1997; Peters et al., 2003). Sklash and Farvolden (1979) demonstrated, a considerable time ago, the dominant contribution of groundwater to the storm hydrograph of small watersheds $\left(<4 \mathrm{~km}^{2}\right)$ in Canada using tracer experiments and water table records.

Additionally, many connections exist between the physical, chemical and biological processes that determine the chemical composition of water flowing from catchments (Christophersen and Neal, 1990; Church, 1997). From this point of view the analysis of certain specific events, such as the transition from low to high water levels, is particularly useful for understanding the hydrological behaviour of catchments.

Measuring the chemical composition of running water can help to investigate not only the quantitative hydrological response to a rainfall event but also the proportion of new and old water to better understand the hydrological behaviour of a catchment during hydrological events (Laudon and Slaymaker, 1997) and to predict its hydrochemical response. If it is assumed that solute concentration variations in running water depend on the composition of the different discharge sources, the mixture of two components (new water and old water) can be used to determine the contribution of old water to the total hydrograph (Pinder and Jones, 1969). In this type of research, electrical conductivity (EC) (Pinder and Jones, 1969; Nakamura, 1971; Wetzel, 2003; Zhang et al., 2011) has been widely used as an environmental tracer. The main advantage of using EC as a hydrological tracer is 
that hydrographs can, a priori, be easily decomposed. Further advantages of using EC are that it can be continuously measured and stored in data loggers, and it is easy and cheap to measure.

In the Aixola catchment hydrological impact studies are being carried out in the context of climate change. In order to rise to that challenge, and before trying to assess any impact, it is essential to understand the hydrological dynamics of the catchment. Moreover, this catchment can be considered as representative of a much extended type of forested catchment in the Basque Country, so that it can give us some clues to understand the hydrology and possible future impact of other similar catchments throughout the observation-conceptualization-modelling sequence mentioned in the Braunschweig Declaration (Schumann et al., 2010).

In this context, the aim of this paper is to describe the complexity of the hydrological response of a small forested catchment, on different timescales, and discuss the role of the controlling factors. To achieve these objectives, first, time series analysis was conducted in order to establish a hypothesis concerning the general functioning of the catchment through the relationship between precipitation and discharge on an annual and multiannual scale. Second, rainfall-runoff relationships and relationships among several hydrological variables, including catchment wetness, were explored at the event scale (in 222 events). Finally, the evolution of electrical conductivity during some of the monitored storm events was examined in order to identify the role of "old water" during runoff events.

\section{Study catchment}

The Aixola catchment is located near the geographical centre of the Basque Country, in the province of Gipuzkoa, at an average latitude of $43^{\circ} \mathrm{N}$ and longitude of $1^{\circ} \mathrm{W}$ (Fig. 1). This region is characterized by a humid and temperate climate. The Aixola River drains a headwater catchment of $4.8 \mathrm{~km}^{2}$ where slopes are generally steep, half of them being higher than $35 \%$. It represents a good reference for reforested catchments in the Cantabrian watershed of the Basque Country, where reforested species (Pinus radiata) cover more than $80 \%$ of the area. In the rest of the catchment, Larix decidua and Abies alba, small remaining patches of mixed forest of Fagus sylvatica and Quercus robur, some pasturelands (covering the $10 \%$ of the catchment) and urban areas $(3 \%)$ are found.

The lithology is almost entirely homogeneous with most of the bedrock (94\%) consisting of Upper Cretaceous Calcareous Flysch composed of alternating marl and sandy limestone layers. This bedrock shows a very low permeability. The main types of soils observed in the Aixola catchment are relatively deep cambisols and regosols (FAO, 1991) with measured depths from 0.8 up to 13 meters. The

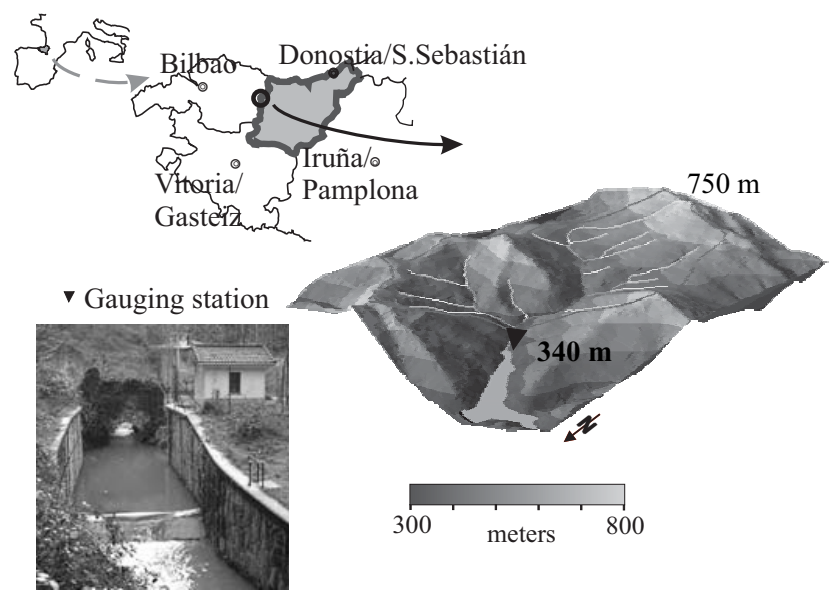

Fig. 1. Location of Aixola catchment and representation of its digital terrain model.

mean annual precipitation in this area in the period from 1986 to 2008 is about $1480 \mathrm{~mm}$ distributed quite evenly throughout the year, and the mean annual discharge calculated for these $22 \mathrm{yr}$ is around $600 \mathrm{~mm} \mathrm{yr}^{-1}$. Annual precipitation for the period of this study (2003-2008) ranged between 1463 and $1624 \mathrm{~mm}$ and runoff between 493 and $808 \mathrm{~mm} \mathrm{yr}^{-1}$ (Table 1). These ranges are within the 25 and 75 percentiles of the data available for the entire 22 -yr period. That is, the precipitation and runoff during the study period were within the average variability of these parameters, meaning that they are not extreme data. The electrical conductivity of the discharge water was measured in samples taken using an automatic sampler, mainly during flood events. It showed an almost constant value of $370 \mu \mathrm{S} \mathrm{cm}^{-1}$ between runoff events, while it fell considerably (to even lower than $200 \mu \mathrm{S} \mathrm{cm}^{-1}$ ) during runoff events (Zabaleta, 2008).

\section{Equipment and methods}

At the outlet of the catchment, there is a gauging station (operated by the Gipuzkoa Provincial Council) where discharge and precipitation are recorded every $10 \mathrm{~min}$. The height of water is measured using a pressure sensor, corrected for variations in air pressure, and a limnigraph, while the precipitation is collected in a rain gauge, the only one in the catchment. An automatic water sampler (SIGMA 900) starts to work during runoff events, when the water height reaches an established threshold. Samples are taken with different time intervals depending on the expected type of precipitation (Zabaleta et al., 2007), so that the 24 samples in the sampler might be taken in a period from 18 to $72 \mathrm{~h}$. Electrical conductivity of water at a reference temperature of $20^{\circ} \mathrm{C}$ is manually measured in the samples taken during runoff events, and occasionally between runoff events, using a Crison 524 conductivity meter. 


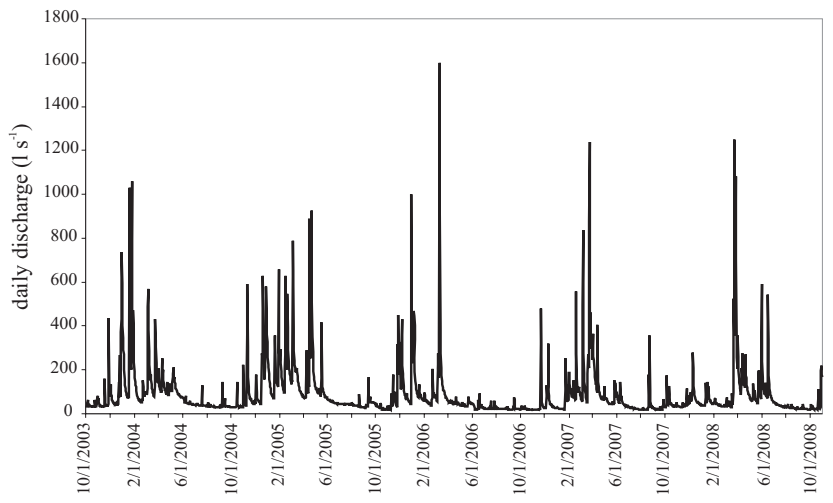

Fig. 2. Daily discharge recorded in Aixola gauging station during the study period (2003-2008).

\subsection{Correlation and spectral analysis}

Correlation and spectral analysis are applied to annual series of precipitation and discharge, on a daily time step for five hydrological years, from November 2003 to October 2008. Daily discharge for the analysed period can be observed in Fig. 2.The mathematical development of the method, as applied in hydrology, is well known and can be found in Mangin (1984).

The simple correlation analysis applied to data series is the autocorrelation function. The values of the autocorrelogram $(r)$ fall quickly to values close to zero if data are of a nearly random nature. On the other hand, the slope of the autocorrelogram is gentler if the events considered have a long-term influence on time series under study. The value of the time step $(k)$ in which $r$ decreases to a value of $0.1-0.2$ allows us to quantify the "memory effect" that Mangin (1984) related to the regulation capacity of the system.

A change from time mode to frequency mode corresponds to the simple spectral analysis that provides information about the transfer mechanisms of the system (filtering function and importance of the reserves). In particular, the spectral density function shows peaks that represent periodic phenomena in the series. This helps to differentiate the different components (seasonal, annual, random) of the time series.

Cross analysis characterizes the transformation of an input series into an output series and it is related to the way the system changes given input signals (in our case, precipitation). In particular, the cross-correlation function represents the impulse response of the system when the rainfall series can be considered to be white noise (Mangin and Pulido-Bosch, 1983). The value of $k$ (time step, in days) for the maximum correlation $(r)$ between series represents the speed of the response to an impulse and the breadth of the peak of the cross-correlogram is related to the duration of
Table 1. Annual precipitation $(P)$, runoff $(R)$, runoff coefficient $(\mathrm{RC})$, and air temperature $(T)$ records for the study period.

\begin{tabular}{lrrrrr}
\hline & $2003-2004$ & $2004-2005$ & $2005-2006$ & $2006-2007$ & $2007-2008$ \\
\hline$P(\mathrm{~mm})$ & 1463 & 1494 & 1457 & 1624 & 1472 \\
$R(\mathrm{~mm})$ & 665 & 808 & 493 & 512 & 534 \\
$\mathrm{RC}(\%)$ & 45 & 54 & 34 & 32 & 43 \\
$T\left({ }^{\circ} \mathrm{C}\right)$ & 12.0 & 12.4 & 12.7 & 12.6 & 12.0 \\
\hline
\end{tabular}

the input impulse in the system and the regulation capacity of the catchment.

As we noted in the Introduction, even though time series analysis has been widely used in hydrology, there are some aspects that must be taken into consideration before interpreting the results and drawing conclusions. The memory effect of a system may vary from one year to the next, so the analysis of just one hydrological year should not be used to characterize the system in the longer term. Further, the hydrological response of the system may vary, in line with changes in the regulation function, which depends on the distribution of precipitation over the course of the year.

In addition, the correlogram does not depend on the values of the runoff series but rather on the form of the time series, so the height and width of the runoff peaks is more important than the absolute values; as Grasso and Jeannin (1994) concluded, the sharper the hydrograph, the more rapid the decrease in the runoff autocorrelogram. Therefore, the duration of storm events and the depth of precipitation also have an important influence on the results of the analysis.

In order to consider these limitations in our analysis and to examine the influence of interannual variability in rainfall, time series analysis was performed for two sets of data: (i) for the data series of daily precipitation and discharge for each of the five hydrological years separately, and (ii) for the temporal series of the whole five-year hydrological period (2003-2008).

\subsection{Streamflow response at the event scale}

Rainfall-runoff relationships at the event scale were studied for events occurring from 2003 to 2008. Only rainfall events in which total precipitation exceeded $1 \mathrm{~mm}$ (in the rain gauge at the outlet, Fig. 1) and the corresponding flow peak was clearly identifiable were considered. Further, runoff events with successive and very close flow peaks were excluded from the analysis. In this way, 222 events were selected for analysis.

The following variables were calculated for each rainfall-runoff event: total precipitation generating the event $\left(P_{\mathrm{t}}, \mathrm{mm}\right)$; maximum precipitation intensity and maximum discharge during the event $\left(\mathrm{IP}_{\max }, \mathrm{mm} 10 \mathrm{~min}^{-1}\right.$ and $Q_{\max }$, $\mathrm{L} \mathrm{s}^{-1}$, respectively); total event runoff depth $\left(Q_{\mathrm{e}}, \mathrm{mm}\right)$; ratio of maximum discharge to discharge prior to the event $\left(Q_{\max } / Q_{\mathrm{o}}\right)$; runoff coefficient $(\mathrm{RC})$, which is the ratio of 
the total event runoff depth to the total event precipitation $\left(Q_{\mathrm{e}} / P_{\mathrm{t}}\right)$; and discharge prior to the event $\left(Q_{\mathrm{o}}, \mathrm{L} \mathrm{s}^{-1}\right), Q_{\mathrm{o}}$ being the parameter used to consider initial conditions as no soil moisture or piezometric level data were available for the study site. Measures related to discharge recorded just prior the beginning of the event have been proposed as surrogates for antecedent conditions, as these indices provide reasonably good results in humid regions and it does not force the choice of an antecedent temporal window (Mishra et al., 2005) and it is a better predictor of runoff generation (Longobardi et al., 2003). Relationships between all these variables were assessed.

$Q_{\mathrm{e}}$ was calculated by means of the classic "constant slope" hydrograph separation method proposed by Hewlett and Hibbert (1967). However, as in other studies (Hornbeck, 1973; Latron and Gallart, 2008; Rodriguez-Blanco et al., 2012), we used a value for the original slope for the straight line different than the one suggested in the initial version for several watersheds in the United States. Specifically, instead of the original slope of $13.1 \mathrm{~L} \mathrm{~s}^{-1} \mathrm{~km}^{-2} \mathrm{day}^{-1}$, a less steep value of $1.699 \mathrm{~L} \mathrm{~s}^{-1} \mathrm{~km}^{-2} \mathrm{day}^{-1}$ or $0.0118 \mathrm{~L} \mathrm{~s}^{-1} \mathrm{~km}^{-2} 10 \mathrm{~min}^{-1}$ was selected (Zabaleta et al., 2010). Using the modified equation, event runoff in the Aixola catchment was better separated into two components than with the original value, which cut the falling limb of the hydrographs too early, underestimating the runoff coefficients (Blume et al., 2007; Merz and Blöschl, 2009).

\subsection{Evolution of electrical conductivity during runoff events}

Evolution of EC during flood events and its relationship with discharge was also analysed for 28 of the runoff events. For this purpose, we could only use the subset of events for which water samples were collected and electrical conductivity was manually measured. Events for which complete recovery of EC was not observed were rejected and in events with more than one peak only the last one was taken into account. For selected events, minimum and maximum conductivity during the runoff event and electrical conductivity recovery time were analysed. The minimum conductivity is indicative of the maximum dilution of discharge water, while the maximum conductivity reflects the chemical properties of the waters that usually are present in the catchment, "the old waters", and the recovery time gives an estimate of the time that new waters are present in the runoff event.

\section{Results and discussion}

\subsection{Correlation and spectral analysis}

Time series analysis was performed on the time series data of the Aixola hydrometeorological station. The input was the daily precipitation $(\mathrm{mm})$ and the output the daily discharge

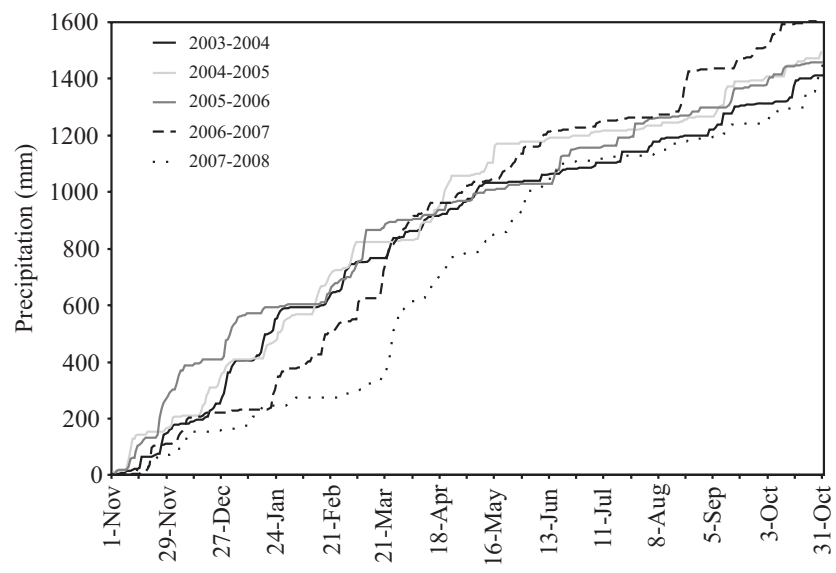

Fig. 3. Accumulated daily precipitation for hydrological years from 2003 to 2008 recorded in Aixola hydrometeorological station.

$\left(\mathrm{L} \mathrm{s}^{-1}\right)$ of this station. The time series covers a period of five hydrological years, running from November 2003 to October 2008, and consists of 1827 measurements. Firstly, each of the hydrological years were considered separately and later the consecutive five hydrological years were analysed as a single series, to better visualize the hydrological response of the catchment on a multi-year timescale and, in particular, to avoid conclusions being influenced by annual variations in input data. In Table 1, annual precipitation, runoff, runoff coefficient and air temperature records are shown for the entire study period. Rainfall distribution in the course of the year is different for each of the five years, as can be seen in accumulated precipitation graphs (Fig. 3), and accordingly, it can be expected that the results of the discharge autocorrelation function for each of the years are different (Fig. 4, Table 2).

The autocorrelation function of daily precipitation (not shown) diminishes very rapidly and quickly reaches the $r=0.2$ level $(k=1,2)$, showing that these series can be considered to be almost random functions. In the case of discharge (Fig. 4a), this function shows an annual and multiannual pattern between 2003 and 2008. As can be observed in Fig. 4a, the decrease in the function is uneven and two discrete phases can be distinguished. In the first one, the discharge drops quickly, over about 10 days, to $r=0.15$, while in the second one the decrease is much slower, reaching $r=0.1$ after 25-50 days in general and as long as 70 days in year 2004-2005. This bimodal behaviour of the autocorrelation function indicates that the catchment response has two components. The first corresponds to the influence of the quicker flow that rapidly reaches the outlet of the catchment, while the second component could be interpreted as the later influence of slower flow from other parts of the catchment with regulation functions affecting discharge for longer periods (deep soils and very low permeability bedrock). The memory effect is therefore high 

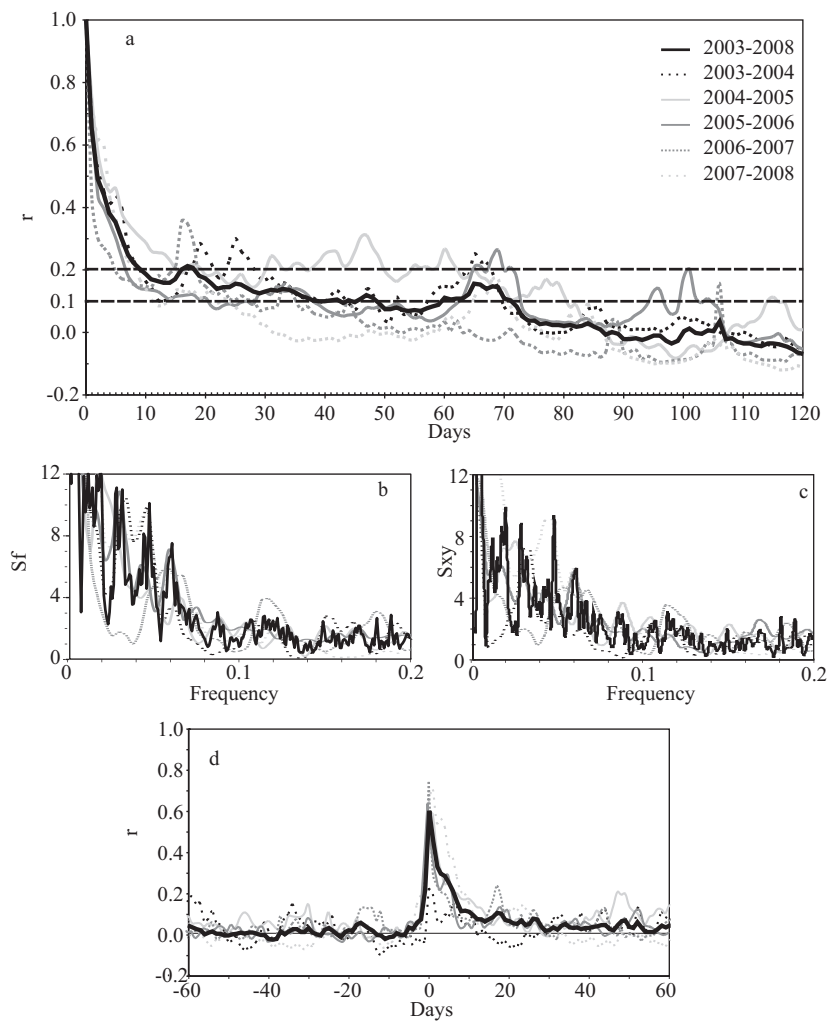

Fig. 4. Time series annual and multiannual analysis of precipitation and discharge daily data registered in Aixola hydrometeorological station from 2003 to 2008. (a) discharge autocorrelogram, (b) discharge simple spectral density function, (c) cross amplitude function, (d) cross-correlogram.

(according to Mangin, 1984) for this system in which the base flow component can be very important.

The spectral density function of the precipitation series (not shown) shows larger peaks at the low frequencies, related to long-term effects, both annual and seasonal. However, peaks are observed at many different frequencies, including mid- and high frequencies, showing the random pattern of precipitation. Figure $4 \mathrm{~b}$ shows the simple spectral density function $\left(S_{\mathrm{f}}\right)$ for the Aixola catchment discharge series. The large peak centred at a frequency of 0.003 (333 days) confirms a notable annual cycle, and this can be attributed to the annual recharge cycle of the catchment. In addition, other high peaks are observed at 0.01 (100 days), 0.018 (55 days), 0.027 (37 days), 0.046 (21 days) and 0.059 (17 days) frequencies corresponding to shorter seasonal, monthly or fortnightly cycles. Moreover, the discharge series cover a relatively large spectral band, as it is necessary to reach frequencies higher than $0.25-0.3$ (period less than 3-4 days) to obtain a good filtering effect. A possible interpretation is that most precipitation events lead to an increase in discharge through the rapid surface runoff. We return to this question in our discussion of the analysis of rainfall runoff events, which can be used to check this interpretation. Comparing cross-amplitude functions $\left(S_{x y}\right)$ with simple spectra $\left(S_{\mathrm{f}}\right)$ (Fig. 4c), it is possible to observe how the system notably amplifies the input signal at the lowest frequencies (up to 0.2). Conversely, at frequencies higher than 0.2 the input is filtered or attenuated.

The cross-correlation function (CCF) shows the rapid response of the catchment to precipitation (2003-2008) expressed by the sharp and narrow peak of Fig. $4 \mathrm{~d}$; there is a time lag less than 1 day, and this response is attributable to the quickflow. Following this peak, the CCF decreases more slowly, between $k=4$ and $k=10$; again this can be interpreted as the influence of a part of the system with a greater storage capacity probably due to the deep soils (up to $13 \mathrm{~m}$ ) of the catchment.

The characteristics deduced for the system from the analysis of the five hydrological years reveal important information concerning the hydrological response of the catchment (Table 2). However, some differences are observed between results obtained for each of the series. It is important not to forget that total precipitation (Table 1) and also precipitation distribution (Fig. 3) are different for each of the years. In relation to this, some authors (Grasso and Jeannin, 1994; Eisenlohr, 1995) have pointed out that results of time series analysis do not just depend on the inherent characteristics of the system analysed but also on the structure of the input data series (precipitation). Considering this, all these authors questioned the role that Mangin (1984) gave to the memory effect as an indicator of the importance of the reserves in the system, because that value depends on the decrease in the autocorrelogram that it is influenced not only by the reserves (internal influence) but also by the precipitation distribution (external influence). Accordingly, the results of the analysis of a multiannual series should be closer to the inherent behaviour of the system than those of single annual series.

\subsection{Streamflow response at the event scale}

To better understand the hydrological response of the Aixola catchment and check the consistency of the interpretations of the time series analysis, we examined the rainfall-runoff relationships at the event scale.

Table 3 shows the statistics for the 222 events analysed for this study. The precipitation $\left(P_{\mathrm{t}}\right)$ that caused the runoff events ranged between 1 and $83.9 \mathrm{~mm}$ (no events with a total precipitation lower than $1 \mathrm{~mm}$ were taken into account). The median of the total discharge volume generated during the event $\left(Q_{\mathrm{e}}\right)$ was $0.13 \mathrm{~mm}$, with a standard deviation of 2.93 and a maximum of $24.78 \mathrm{~mm}$. The ratio of the maximum to the initial discharge $\left(Q_{\max } / Q_{\mathrm{o}}\right)$ ranged between 1.1 and 161.4 and the runoff coefficient $(\mathrm{RC})$ between 0.0025 and 0.4. These values for the runoff coefficient are much higher than the ones calculated by Rodriguez-Blanco et al. (2012) for a humid and temperate forested catchment of $16 \mathrm{~km}^{2}$ in northwestern Spain. As for the conditions prior to the event, 
Table 2. Hydrologic parameters obtained from time series analyses of daily precipitation and discharge registered in Aixola station from 2003 to 2008 . The memory effect is the value of $k$ for $r=0.1-0.2$ in the discharge correlogram, the spectral band is the frequency from which the simple spectrum of discharge is negligible $\left(S_{\mathrm{f}}<1\right)$ and the quickness of the response is the value of $k$ for the maximum value of the cross-correlogram.

\begin{tabular}{lllllll}
\hline & $2003-2004$ & $2004-2005$ & $2005-2006$ & $2006-2007$ & $2007-2008$ & $2003-2008$ \\
\hline Memory effect (days) & $30-40$ & $60-80$ & $10-35$ & $20-30$ & $10-25$ & $10-50$ \\
Spectral band & 0.21 & 0.23 & 0.24 & 0.5 & 0.13 & 0.25 \\
Quickness response (days) & 0 & 0 & 0 & 0 & 1 & 0 \\
\hline
\end{tabular}

Table 3. Median, maximum, minimum and standard deviation of total precipitation $\left(P_{\mathrm{t}}\right)$, initial discharge $\left(Q_{\mathrm{o}}\right)$, relationship between maximum discharge and initial discharge $\left(Q_{\max } / Q_{\mathrm{o}}\right)$, event runoff $\left(Q_{\mathrm{e}}\right)$ and runoff coefficient $(\mathrm{RC})$ for the 222 rainfall events recorded between 2003 and 2008 .

\begin{tabular}{lrrrrr}
\hline & $P_{\mathrm{t}}(\mathrm{mm})$ & $Q_{\mathrm{o}}\left(\mathrm{L} \mathrm{s}^{-1}\right)$ & $Q_{\max } / Q_{\mathrm{o}}$ & $Q_{\mathrm{e}}(\mathrm{mm})$ & $\mathrm{RC}$ \\
\hline Med & 5.6 & 44.6 & 2.8 & 0.13 & 0.02 \\
Max & 83.9 & 176.0 & 161.4 & 24.78 & 0.40 \\
Min & 1.0 & 16.0 & 1.1 & 0.0037 & 0.0025 \\
St. dv. & 11.2 & 29.7 & 15.3 & 2.93 & 0.05 \\
\hline
\end{tabular}

the discharge at the start of the events $\left(Q_{\mathrm{o}}\right)$ ranged from 16 to $176 \mathrm{~L} \mathrm{~s}^{-1}$.

In this catchment, total rainfall and runoff depth were found to be strongly correlated at the event scale $(R=$ 0.68; Zabaleta et al., 2007), despite a moderate degree of scattering. This scattering may be related to the high variability in the runoff coefficient over the course of the year, the runoff coefficient (RC) being a good indicator of the hydrological response of a catchment to a rainfall event (Zabaleta et al., 2010). This parameter is strongly related with the quickflow component of the hydrograph.

Figure 5 shows the monthly evolution of the runoff coefficient for the 222 events recorded between 2003 and 2008, as well as the total $P(\mathrm{~mm})$ for each event. It can be seen from the figure that there is a high variability in this coefficient: quickflow varies from 0.0025 to 0.4 of the total rainfall recorded for the event. Further, differences are observed in the runoff coefficient over the course of the year. The coefficient is higher than 0.01 from December to April, with some events that have a RC of over 0.2 in December and March (when highest runoff coefficients were obtained). Conversely, many events from July to October have runoff coefficients lower than 0.01 , even with large amounts of precipitation, and the RC is always lower than 0.1. Lana-Renault et al. (2007) reported similar seasonal patterns for the Arnás mountainous catchment in the Pyrenees. Gallart et al. (1997), among others, observed that runoff coefficients tended to be significantly higher in winter than in summer due to the higher contribution of summer rainfall to soil-moisture recharge and to the higher evapotranspiration during this season.

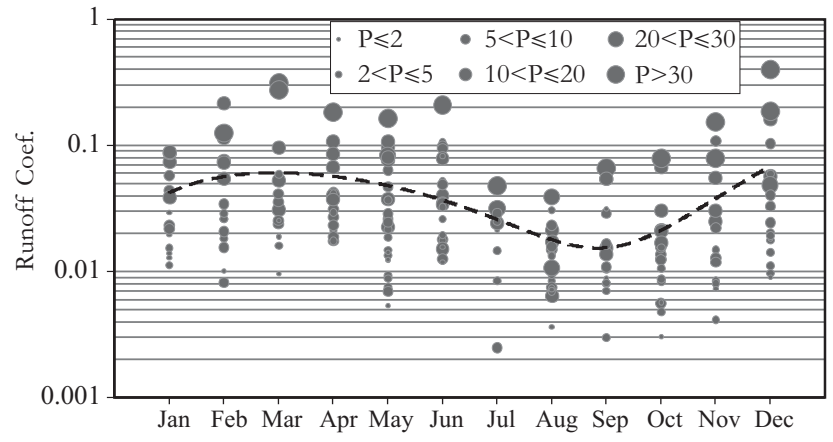

Fig. 5. Distribution along the year of runoff coefficients estimated for rainfall-runoff events observed between 2003 and 2008 in Aixola catchment. Size of the black dots represents total precipitation $(\mathrm{mm})$ recorded during the event.

In the Aixola catchment, the variability in the runoff coefficient, or the distribution of the quickflow and slowflow (as defined in the previous section) in the hydrograph, may be related to the seasonal dynamics of the wetness conditions in the catchment, particularly to the evolution from wetter conditions in winter to dryer ones in summer, with efficiency of the precipitation to generate runoff becoming lower. November, and May-June can be considered as the months of transition between dry and wet periods at the beginning of autumn and between wet and dry periods in the late spring, respectively. At the beginning of the hydrological year, from September to November, catchment response to the rainfall events increases and observed runoff coefficients are higher as the catchment wets up. After high runoff coefficients during the wet period, in May and June, wetness of the catchment and, hence, the runoff response starts to decrease. At the end of the hydrological year, a dryer period is observed with lower runoff coefficients. In fact, the runoff coefficient (the amount of quickflow) is higher for similar total precipitation amounts as discharge prior to the event increases. This shows that even if correlation coefficients between antecedent discharge and event discharge are not high $(0.45, p<0.01$; Zabaleta et al., 2007), previous wetness conditions are important in runoff generation processes and in the contribution of the different components of the hydrograph. Similar results for the relationship between soil 


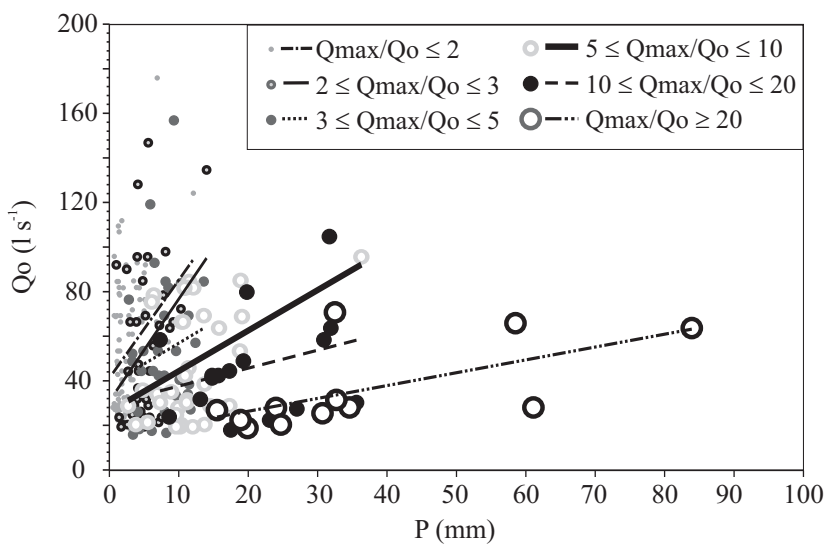

Fig. 6. Event precipitation, recorded at the gauging station, (mm) needed to produce an increase in the initial discharge $\left(Q_{\mathrm{o}}\right.$, $\mathrm{Ls}^{-1}$ ). Grey spots represent discharge increase expressed as the ratio $Q_{\max } / Q_{\mathrm{o}}$. Size of the spot corresponds to discharge-raising magnitude. Black lines represent relationships for events where the ratio $Q_{\max } / Q_{\mathrm{o}}$ is similar.

water content and runoff were found by other authors in temperate humid catchments (Pfister et al., 2002; Merz et al., 2006; Norbiato et al., 2009; Penna et al., 2011).

As well as runoff coefficient, discharge increase is also dependent on antecedent conditions. To assess the influence of antecedent conditions on the high variability in hydrological response, relationships between total event precipitation and increase in discharge were analysed, taking into account initial discharge. Figure 6 shows the relationship between event precipitation $\left(P_{\mathrm{t}}, \mathrm{mm}\right)$, associated hydrological response expressed as relative increase in discharge (ratio of maximum discharge to discharge prior to the event, $\left.Q_{\max } / Q_{\mathrm{o}}\right)$ and initial discharge $\left(Q_{\mathrm{o}}, \mathrm{L} \mathrm{s}^{-1}\right)$. It reflects the amount of precipitation required to generate a certain increase in discharge of the catchment for a given wetness condition, reflected by the initial discharge. To produce an increase of $2>Q_{\max } / Q_{0}>1$ with an initial discharge of $50 \mathrm{~L} \mathrm{~s}^{-1}$, around $2 \mathrm{~mm}$ of rainfall is sufficient, but if the initial discharge is higher, $80 \mathrm{~L} \mathrm{~s}^{-1}$, the amount of precipitation needed to produce a similar increase in discharge is also higher, $8 \mathrm{~mm}$. In addition, similar values of precipitation of around $8 \mathrm{~mm}$ can generate very different increases in runoff, depending on initial conditions, that is, $Q_{0}$. Specifically, a 5 to 10 -fold increase in runoff can be observed with an initial discharge of $40 \mathrm{~L} \mathrm{~s}^{-1}$, whereas discharge can rise by a factor of up to 20 when initial discharge is about the half, $20 \mathrm{~L} \mathrm{~s}^{-1}$.

Additionally, there is a lower limit of the antecedent condition for runoff generation. Western and Grayson (1998) clearly showed that surface runoff was a process controlled by catchment wetness conditions, with runoff coefficients, or contribution of the quickflow component, increasing abruptly when a certain moisture threshold was exceeded. The

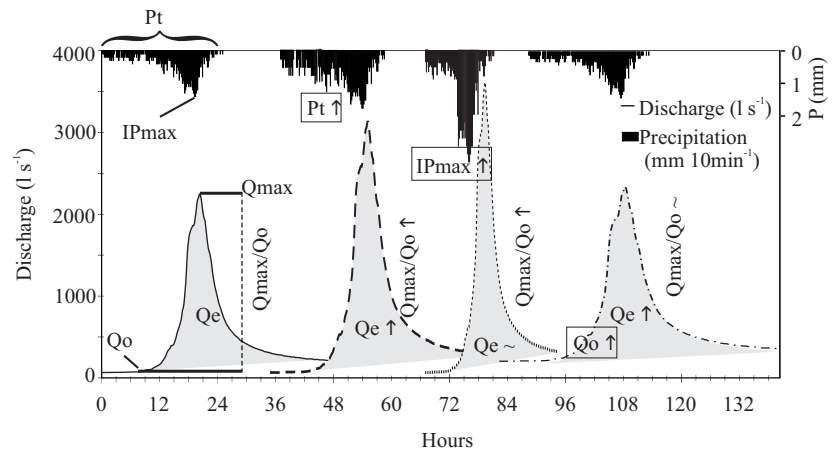

Fig. 7. Graphical interpretation of the influence of precipitation $\left(P_{\mathrm{t}}\right)$, maximum precipitation intensity $\left(\mathrm{IP}_{\max }\right)$ and initial discharge $\left(Q_{\mathrm{o}}\right)$ in hydrological response of Aixola catchment $\left(Q_{\max }, Q_{\mathrm{e}}\right.$, $Q_{\max } / Q_{\mathrm{o}}$ ). Timescale is approximate. (a) shows the parameters that are being assessed and is the original hydrograph that will change according to the changes in precipitation or initial discharge. (b), (c) and (d) represent hydrographs generated when there is an increase in total precipitation (b), precipitation intensity (c) and initial discharge (d).

existence of this kind of threshold has also been suggested more recently by other authors (Tromp-van Meerveld and McDonnell, 2005; Latron and Gallart, 2008; James and Roulet, 2009; Zehe et al., 2010; Penna et al., 2011) in catchments with varying relationships between soil moisture and runoff coefficient, likely due to differences in soil type, soil depth and climatic conditions. However, this lower limit is not the same for all precipitation events that occur in the Aixola catchment. A precipitation event of $1 \mathrm{~mm}$ can generate an increase in discharge with an antecedent discharge of $28 \mathrm{~L} \mathrm{~s}^{-1}$, while if the initial discharge is lower, $20 \mathrm{~L} \mathrm{~s}^{-1}$ for example, the precipitation needed to generate an increase in discharge is higher, around $4 \mathrm{~mm}$. It also seems that, with data from the five-year period, no runoff is generated with initial discharges below $16-18 \mathrm{~L} \mathrm{~s}^{-1}$. This is because $16 \mathrm{Ls}^{-1}$ is the minimum discharge recorded at the gauging station during the study period and only on 23 days, of the 1827 of the total series, was the daily average discharge lower than $18 \mathrm{~L} \mathrm{~s}^{-1}$ (21 of them in 2006-2007).

An attempt to draw relationships between precipitation and initial discharge for events with a similar $Q_{\max } / Q_{0}$ ratio was done in Fig. 6. The slopes of those visual lines illustrate the strong influence of initial discharge on catchment hydrological response in terms of increase in discharge. As initial discharge $\left(Q_{0}\right)$ increases, the precipitation required to observe a response for the same $Q_{\max } / Q_{\mathrm{o}}$ ratio is higher. This fact is even more evident for higher values of $Q_{\max } / Q_{\mathrm{o}}$ : for $Q_{\max } / Q_{0} \geq 20$ the slope for the regression between precipitation and initial discharge is very gentle. These relations can be used to estimate the magnitude of the hydrological response to a forecasted precipitation in terms of increase in discharge when initial discharge is known. 
The potential influence of other factors on hydrological response was assessed using linear correlations (Pearson's correlation coefficient and its significance level) of increase in discharge $\left(Q_{\max } / Q_{\mathrm{o}}\right)$ and in runoff coefficient $\left(Q_{\mathrm{e}} / P_{\mathrm{t}}\right)$ with total precipitation $\left(P_{\mathrm{t}}\right)$, maximum 10-min precipitation intensity $\left(\mathrm{IP}_{\max }\right)$ and initial discharge at the start of the event $\left(Q_{\mathrm{o}}\right)$. Figure 7 shows the graphical interpretation of these linear correlations. A significant positive correlation was found between runoff coefficient and total precipitation $(R=$ $0.74 ; p<0.01)$, meaning that as total precipitation increases the contribution of quickflow is higher (Fig. 7b). Increase in discharge was also significantly positively correlated with the total event precipitation $(R=0.61 ; p<0.01)$ (Fig. 7b). On the other hand, no statistically significant relationship was found between runoff coefficient and precipitation intensity ( $R=0.07$ ), suggesting that the contribution of the quickflow component does not depend on maximum rainfall intensity and, as a consequence this parameter does not influence event runoff depth (Fig. 7c). However, the relationship between maximum rainfall intensity and increase in discharge is positive and significant $(R=0.58, p<0.01)$ (Fig. 7c). In this catchment, as in other vegetated catchments (Hewlet et al., 1977; Lana-Renault et al., 2007; Rodriguez-Blanco et al., 2012), rainfall intensity has a negligible effect on the amount of quickflow present in the total discharge, but not on the magnitude of the peak flow.

No statistically significant correlation was found between initial discharge and increase in discharge $(R=-0.07)$, but the relationship between initial discharge and runoff coefficient was significant $(R=0.4, p<0.01)$ (Fig. 7d). This suggests that there is no linear relationship between catchment wetness and the magnitude of the discharge peak even though wetness does play a significant role in the relationship between precipitation and increase in discharge, as seen in Fig. 6, as well as in the event runoff depth $\left(Q_{\mathrm{e}}\right)$.

To illustrate the factors that influence the hydrological response and its magnitude in the Aixola catchment, pairs of events with similar precipitation amounts were compared and the relationship between antecedent conditions and streamflow response and precipitation intensity and magnitude of hydrological response were analysed at the event scale (Fig. 8). The event illustrated on the upper left side of the figure (Fig. 8a) was recorded in January 2008, under wet conditions with an initial discharge of $45 \mathrm{~L} \mathrm{~s}^{-1}$. The runoff coefficient calculated for this event was, as expected, high, reaching a value of 0.1 . The event on the right (Fig. 8b) was recorded in June 2006, under dryer conditions with an initial discharge of $18 \mathrm{~L} \mathrm{~s}^{-1}$. The runoff coefficient in this case is low (0.02). As the precipitation amount $(\sim 17 \mathrm{~mm})$ and the maximum intensity $\left(\sim 2.5 \mathrm{~mm} 10 \mathrm{~min}^{-1}\right)$ in both cases are similar, the ratio between maximum and initial discharges is also quite similar (11-17). In contrast, in the lower part of the figure (Fig. 8c and d) two events showing similar total precipitation and initial discharge but quite different precipitation
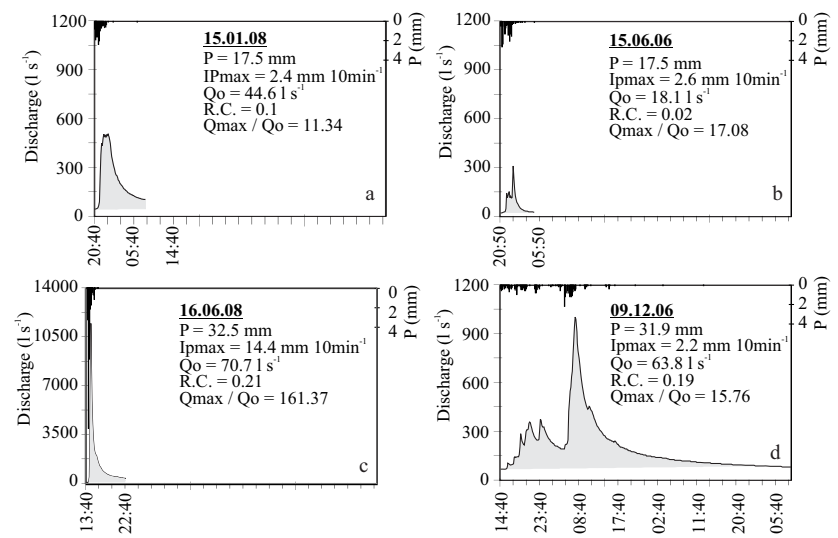

Fig. 8. Example of events with different hydrological response. Precipitation $(P, \mathrm{~mm})$, maximum intensity of precipitation (mm $\left.10 \mathrm{~min}^{-1}\right)$, initial discharge $\left(Q_{\mathrm{o}}, \mathrm{L} \mathrm{s}^{-1}\right)$, runoff coefficient (RC) and discharge increase $\left(Q_{\max } / Q_{\mathrm{o}}\right)$ are included for each event.

intensity are compared. For the event on the right (Fig. 8c), the ratio between maximum and initial discharges is lower (15.76) because of the lower precipitation intensity $\left(2.2 \mathrm{~mm} 10 \mathrm{~min}^{-1}\right)$. In contrast, the magnitude of the increase in discharge in the event on the left (Fig. 8d) was 10 times higher than the previously mentioned, reaching the value of 161.37 due to a much higher intensity of precipitation $\left(14.4 \mathrm{~mm} 10 \mathrm{~min}^{-1}\right)$.

Figures 5, 6 and 8 illustrate the different hydrological behaviour of the Aixola catchment under different initial conditions and different rainfall patterns, with events that show higher runoff coefficients (quickflow) and smaller increases in discharge under lower intensity rainfalls and wetter conditions that usually occur from December to April, and other events showing lower runoff coefficients and higher increases of discharge under higher precipitation intensity and dryer conditions mostly occurring from July to September-October. These results are similar to those found by Rodriguez-Blanco et al. (2012) for the Corbeira catchment.

\subsection{Evolution of electrical conductivity during runoff events}

The evolution of EC during runoff events was examined in 28 of the events in order to explore the contribution of the old water to the total discharge during runoff events. The behaviour of this tracer during the runoff events was very homogeneous across the range of different hydrological conditions of the catchment seen throughout the study period. In all cases, a very rapid increase was observed in EC after the minimum value of it and the peak of discharge, both taking place at the same time, and it seems that neither the total nor the intensity of the event precipitation significantly influence the recovery to the initial EC, which is almost 


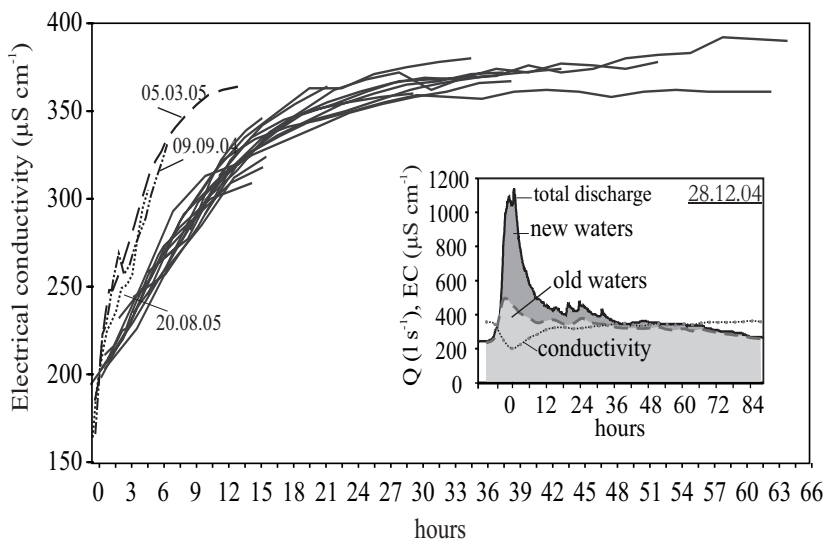

Fig. 9. Hourly evolution of electrical conductivity $\left(\mu \mathrm{S} \mathrm{cm}^{-1}\right)$ in river waters after minimum electrical conductivity of 28 runoff events registered in Aixola catchment. $t=0 \mathrm{~h}$ corresponds to $200 \mu \mathrm{S} \mathrm{cm}^{-1}$ electrical conductivity. An example of hydrograph separation using conductivity is included.

constant ( $\left.370 \mu \mathrm{S} \mathrm{cm}^{-1}\right)$ (Fig. 9). Moreover, runoff events that occurred in very different wetness conditions $\left(Q_{\mathrm{o}}\right.$ between 24.7 and 124.3) and runoff coefficients (between 0.006 and 0.109) show the same rapid increase in EC after the minimum registered in each runoff event. This increase is shown in Fig. 9. The minimum EC is around $200 \mu \mathrm{S} \mathrm{cm}^{-1}$ for most of the events and so this value has been selected to identify the time $t=0$ for all cases in order to make it easier to compare EC recovery in different events. When the hydrograph showed more than one peak only the evolution after the last peak was represented. It can be clearly seen that the response is homogeneous and also that only a short time is required to recover to the initial EC of the waters. The slope is relatively steep at the beginning, flattens off after around $15 \mathrm{~h}$ and full recovery of the EC is reached after around $33 \mathrm{~h}$, indicating a progressive increase in the presence of pre-event waters in the outlet.

The value of $370 \mu \mathrm{S} \mathrm{cm}^{-1}$, measured at the outlet of the catchment between runoff events, is the maximum observed in Aixola waters, and is almost constant along the hydrological year. Given this, it is assumed that this value indicates the chemical properties of waters that generally are present in the catchment, referred to as "the old waters" (baseflow + subsurface flow waters) EC. Further, a lower limit can also be observed in the figure, as in most cases the minimum conductivity measured during events does not fall below $200 \mu \mathrm{Scm}^{-1}$. Considering that rainwater EC values in this area are known to vary between 60 and $80 \mu \mathrm{S} \mathrm{cm}^{-1}$ (estimated from sporadic measurements in the field), $200 \mu \mathrm{S} \mathrm{cm}^{-1}$ as a minimum conductivity during the runoff event is comparatively high, and indicates that a relatively high proportion of old or pre-event water $(40-45 \%)$ is present in discharge during runoff peaks. Using the abovementioned end-members and their ECs
( $70 \mu \mathrm{S} \mathrm{cm}^{-1}$ for rainwater and 370 for baseflow + subsurface flow) the contribution of pre-event water to the total event water depth has been estimated to be between the $55 \%$ and $85 \%$, being lower in longer events with various peaks and higher in shorter runoff events with only one peak. These percentages are in accordance with the documented importance of subsurface flow in the generation of runoff in humid catchments (Hewlett and Hibbert, 1967; Sklash and Farvolden, 1979; Laudon and Slaymaker, 1997; Zehe et al., 2010, and others).

The runoff coefficient for the events studied ranges between 0.006 and 0.109 , a broad range compared to that of the old water contribution during the event (55-85\%), showing that a significant proportion of quickflow is old water that was stored in the deep soils of the catchment (up to 13 meters deep). This high percentage of old water in the quickflow component might be related, as reported by many authors (Kirkby, 1988; Anderson et al., 1997; Bonell, 1998), by a translatory flow process, in which old water with high electrical conductivity is pushed by new water.

Some exceptions to this general behaviour can be found in three of the events, namely, EC recovery is much quicker. In two of these events, in September 2004 and August 2005, minimum EC was lower than usual $\left(166\right.$ and $163 \mu \mathrm{S} \mathrm{cm}^{-1}$, respectively). The events occurred under low initial discharge conditions ( $Q_{\mathrm{o}}$ was 25.6 and $28 \mathrm{~L} \mathrm{~s}^{-1}$, respectively) and with very intense (6.6 and $5.4 \mathrm{~mm}$ in $10 \mathrm{~min}$ respectively) and short duration precipitation that generated large increases in discharge (72.9 and 38.6 were the values of $Q_{\max } / Q_{\mathrm{o}}$ ) and comparatively low EC values. In these cases, high precipitation intensities would favour infiltration excess runoff and so new water would reach catchment outlet more easily. On the other hand, the quick increase in EC was favoured by the short duration of the rainfall event. The third case, the event during March 2005, is quite different as the atypical results can be attributed to snow melt (unusual for this area).

Though the generally loamy character of the deep soils in the catchment would favour infiltration, infiltration excess runoff would be happening in urban areas $(3 \%$ of the catchment) but also in pasturelands (10\%) as well as in the forest itself, favoured, on one side, by the dense net of forest service paths, where the soil is compacted, and, on the other, by the steep slopes (more than the half of the catchment has slopes higher than the $35 \%$ ). In addition to infiltration excess runoff, saturation excess runoff can also be observed locally, although not very frequently, in some pasture areas where the soils are locally more clayey. After high amounts of antecedent precipitation happen, perched water levels can appear near the surface saturating the top part of the soil. 


\section{Conclusions}

This paper presents the streamflow response of a small humid-temperate catchment (Aixola catchment, $4.8 \mathrm{~km}^{2}$; the Basque Country), on different timescales based on data recorded between 2003 and 2008.

Correlation and spectral analysis can be used to compare and classify hydrological systems when the input signal is the same for all of them. However, as rainfall varies between catchments and years, this comparison is biased by the effect of different input time series (rainfall). Inferences derived from this analysis will always remain very qualitative, though in some particular cases they can provide useful information about the system that should be verified or complemented by other methods, even changing the observation scale. On the other hand, information about internal behaviour cannot be derived. In this paper, daily time series analysis was used to establish a hypothesis concerning the general functioning of the catchment through the relationship between precipitation and discharge on an annual and multiannual scale. It is shown that the results of the analysis of a multi-year series are closer to the inherent behaviour of the system than those of one year series. Results from correlation and spectral analysis evidence the high regulation capacity the Aixola catchment, being the bedrock of very low permeability, is provided by its deep soils (depths from 0.8 up to $13 \mathrm{~m}$ ) more than by a rock aquifer. The very deep soils are the ones that make the system highly regulated and support the base flow of the river.

The analysis reported at the event scale in Aixola catchment (222 events) provided information to check and improve the hypothesis proposed on the basis of the time series analysis. The quick response of the catchment to almost all the rainfall events and the existence of a part of the catchment with a greater storage capacity (deep soils) deduced from the correlation and spectral analyses agree with runoff event scale data analysis, including correlations between different variables and the evolution of the EC. However, the event analysis underlined the non-linearity of the system, as antecedent conditions play a significant role in the catchment response, and the importance of "pre-event waters" in the quickflow was observed.

In addition, event scale rainfall-runoff analysis made it possible to quantify the hydrological response to some degree. The runoff coefficient (RC), related to the quickflow component of the hydrograph, shows a clear seasonality in the course of the year, with a wet period with higher runoff coefficients, a dryer period with lower runoff coefficients and two transition periods where the catchment is wetting up or drying down. This pattern evidences the dependence of RC on the initial discharge value in each event. Further, runoff response, in terms of increase in discharge, can be estimated because it strongly depends on the initial discharge for the given event (wetness of the basin) and total rainfall. Additionally, it seems that infiltration excess runoff can play an important role during intense precipitation events that occur during the driest periods, as such events show higher $\mathrm{RC}$ (more water coming from the quickflow component of the catchment) and lower minimum electrical conductivity values, combined with higher percentages of new water in the total discharge. The existence of urban areas, steep slopes and forest service paths, where the soil has a lower infiltration capacity, suggests that infiltration excess runoff would be the main mechanism that new water has to quickly reach the outlet of the catchment. However, saturation excess runoff can also be very locally observed, in some pasture areas where perched water levels can appear near the surface saturating the top part of the soil.

Finally, the evolution of the electrical conductivity of waters during runoff events shows that, usually, pre-event waters represent a high percentage of total runoff depth of the events (55-85\%), suggesting that not all the quickflow is "new water" but rather that water stored in the soil and translatory flow, as a process, play a notable role. Indeed, these findings show how EC data enable the time origins (event or pre-event waters) of quickflow to be established.

At this stage of the research there is not data enough to discriminate to which extent each of the runoff generation processes mentioned takes place or the exact pathways contributing quick- and slowflow, and new and old waters. Additionally, further research is needed to better understand the influence of land use and soil moisture on initial discharge in order to obtain a more precise conceptualization of the hydrological processes taking place within Aixola catchment. To that end, piezometers and devices to continuously measure electrical conductivity of waters are being installed in this catchment.

Acknowledgements. The authors wish to thank the Environment and Land Management Department of the Gipuzkoa Provincial Council, the University of the Basque Country (UFI 11/26), and the Basque Government (Consolidated Group IT516-10 and the K-Egokitzen project-ETORTEK IE10-277) for supporting this research.

Edited by: A. Butturini

\section{References}

Abdul, A. S. and Gillham, R. W.: Field studies of the effects of the capillary-fringe on streamflow generation, J. Hydrol., 112, 1-18, 1989.

Anderson, S. P., Dietrich, W. E., Torres, R., Montgomery, D. R., and Loague, K.: Concentration-discharge relationships in runoff from a steep, unchanneled catchment, Water Resour. Res., 33, 211-225, 1997.

Antigüedad, I.: Systèmes aquifères karstiques du Pays Basque, in: Karst Hydrology, IAHS-AISH Publ., 247, 127-136, 1997. 
Blume, T., Zehe, E., and Bronstert, A.: Rainfall runoff response, event-based runoff coefficients and hydrograph separation, Hydrolog. Sci. J., 52, 843-862, 2007.

Bonell, M.: Selected challenges in runoff generation research in forests from the hillslope to headwater drainage basin scale, J. Am. Water Resour. As., 34, 765-785, 1998.

Bouanani, A., Baba Hamed, K., Mania, J., and Bensalah, M.: Le comportement d'un système hydrologique en climat méditerranéen par l'analyse corrélatoire et spectrale des débits et des pluies. Cas de trois sous bassins sud-méditerranéens: (oued Sebdou, Moulah et Isser - Tafna - Algérie), Revue des Sciences de l'eau, 18, 215-224, 2005.

Christophersen, N. and Neal, C.: Linking hydrological, geochemical, and soil chemical processes on the catchment scale: an interplay between modelling and field work, Water Resour. Res., 26, 3077-3086, 1990.

Church, M. R.: Hydrochemistry of forested catchments, Annu. Rev. Earth Pl. Sc., 25, 23-59, 1997.

Efstathios, L. B. and Abiose, M. O.: Cross-spectral analysis of rainfall and runoff for Raritan and Mullica river basins in New Jersey, J. Hydrol., 21, 61-79, 1974.

Eisenlohr, L.: Variabilité des réponses naturelles des aquiféres karstiques: De l'identification de la réponse globale vers la connaissance de la structure de l'aquifère. Thèse Univ. Neuchâtel, 123 pp., 1995.

Eisenlohr, L., Bouzelboudjen, M., Király L., and Rossier, Y.: Numerical versus statistical modelling of natural response of a karst hydrogeological system, J. Hydrol., 202, 244-262, 1997.

FAO, UNESCO, ISRIC: Mapa mundial de suelos, Leyenda revisada, Informe sobre el recurso mundial del suelo 60., Trad. por Carballas, Macías, Díaz, Carballas y Fernández, Sociedad Española de la Ciencia del Suelo, Santiago de Compostela, España, 1991.

Gallart, F., Latron, J., Llorens, P., and Rabadá, D.: Hydrological functioning of Mediterranean mountain basins in Vallcebre, Catalonia: some challenges for hydrological modelling, Hydrol. Process., 11, 1263-1272, 1997.

Grasso, D. A.: Interprétation des responses couplées hydraulique et chimique des sources karstiques (essai d'inférence de la structure de systèmes karstiques), Thése Univ. Neuchâtel, 120 pp., 1998.

Grasso, D. A. and Jeannin, P.: Etude critique des méthodes d'analyse de la réponse globale des systèmes karstiques, Application au site de Bure (JU, Suisse), Bulletin d'hydrogéologie, 13, 87-113, 1994.

Hanna, E. J.: Multiple time series, Wiley, New York, 536 pp., 1970.

Hewlett, J. D. and Hibbert, A. R.: Factors affecting the response of small watersheds to precipitation in humid areas, in: Forest Hydrology, edited by: Sooper, W. D. and Lull, H. W., Pergamon, 275-290, 1967.

Hewlett, J. D., Fortson, J. C., and Cunningham, G. B.: Effect of rainfall intensity on storm flow and peak discharge from forest land, Water Resour. Res., 13, 259-266, 1977.

Hornbeck, J. W.: Storm flow from hardwood-forested and cleared watersheds in New Hampshire, Water Resour. Res., 9, 346-354, 1973.

James, A. L. and Roulet, N. T.: Antecedent moisture conditions and catchment morphology as controls on spatial patterns of runoff generation in small forest catchments, J. Hydrol., 377, 351-366, 2009.
Jeannin, P. and Sauter, M.: Analysis of karst hydrodynamic behaviour using global approaches: a review, Bulletin d'hydrogéologie, 16, 31-48, 1998.

Jenkins, G. M. and Watts, D. G.: Spectral analysis and its applications, Holden-Day, San Francisco, 1968.

Jo, Y.-J. and Lee, J.-Y.: Time series analysis of hydrologic data obtained from a man-made undersea LPG cavern, Eng. Geol., 113, 70-80, 2010.

Jordan, J. P.: Identification et modelisation des processus de génération des crues, Application au bassin versant de la Haute-Mentue, PhD Thesis, Ecole Polytechnique Fédérale de Lausanne, 318 pp., 1992.

Kirkby, M.: Hillslope runoff processes and models, J. Hydrol., 100, 315-339, 1988.

Kirnbauer, R., Blöschl, G., Haas, P., Müller, G., and Merz, B.: Identifying space-time patterns of runoff generation - A case study from the Löhnersbach catchment, Austrian Alps, in: Global change and mountain regions - a state of knowledge overview, edited by: Huber, U., Bugmann, H., and Reasoner, M., Springer Verlag, 309-320, 2005.

Lana-Renault, N., Latron, J., and Regües, D.: Streamflow response and water-table dynamics in a sub-Mediterranean research catchment (Central Pyrenees), J. Hydrol., 347, 497-507, 2007.

Latron, J.: Estudio del funcionamiento hidrológico de una cuenca mediterránea de montaña (Vallcebre, Pirineos Catalanes), $\mathrm{PhD}$ Thesis, Universidad de Barcelona, 210 pp., 2003.

Latron, J. and Gallart, F.: Runoff generation processes in a small Mediterranean research catchment (Vallcebre, Eastern Pyrenees), J. Hydrol., 358, 206-220, 2008.

Laudon, H. and Slaymaker, O.: Hydrograph separation using stable isotopes, silica and electrical conductivity: an alpine example, J. Hydrol., 201, 82-101, 1997.

Lee, J.-Y. and Lee, K. K.: Use of hydrologic time series data for identification of recharge mechanism in a fractured bedrock aquifer system, J. Hydrol., 229, 190-201, 2000.

Longobardi, A., Villani, P., Grayson, R. B., and Western, A. W.: On the relationship between runoff coefficient and catchment initial conditions, in: Proceedings of MODSIM 2003, 867-872, 2003.

Mangin, A.: Utilisation des analyses correlátoires et spectrales dans l'approche des systèmes hydrologiques, CR Acad. Sci. Paris, 293, 401-404, 1981a.

Mangin, A.: Apport des analyses correlátoires et spectrales croisées dans la connaissance des systèmes hydrologiques, CR Acad. Sci. Paris, 293, 1011-1014, 1981b.

Mangin, A.: Pour une meilleure connaissance des systèmes hydrologiques à partir des analyses corrélatoires et spectrales, J. Hydrol., 67, 25-43, 1984.

Mangin, A. and Pulido-Bosch, A.: Aplicación de los análisis de correlación y espectral en el estudio de acuíferos kársticos, Tecniterrae, 51, 53-65, 1983.

Mathevet, T., Lepiller, M. 1., and Mangin, A.: Application of time-series analyses to the hydrological functioning of an Alpine karstic system: the case of Bange-L'Eau-Morte, Hydrol. Earth Syst. Sci., 8, 1051-1064, doi:10.5194/hess-8-1051-2004, 2004.

Merz, R. and Blöschl, G.: A regional analysis of event runoff coefficients with respect to climate and catchment characteristics in Austria, Water Resour. Res., 45, W01405, doi:10.1029/2008WR007163, 2009. 
Merz, R., Blöschl, G., and Parajka, J.: Spatio-temporal variability of event runoff coefficients, J. Hydrol., 331, 591-604, 2006.

Mishra, S. K., Jain, M. K., Pandey, R. P., and Singh, V. P.: Catchment area-based evaluation of the AMC-dependent SCS-CN based rainfall-runoff models, Hydrol. Process., 19, 2701-2718, 2005.

Molénat, J., Davy, P., Gascuel-Odoux, C., and Durand, P.: Study of three subsurface hydrologic systems based on spectral and cross-spectral analysis of time series, J. Hydrol., 222, 152-164, 1999.

Naef, F., Scherrer, S., and Weiler, M.: A process based assessment of the potential to reduce flood runoff by land use change, J. Hydrol., 267, 74-79, 2002.

Nakamura, R.: Runoff analysis by electrical conductance of water, J. Hydrol., 14, 197-212, 1971.

Negley, T. L. and Eshleman K. N.: Comparison of stormflow responses of surface-mined and forested watersheds in the Appalachian Mountains, USA, Hydrol. Process., 20, 3467-3483, 2006.

Norbiato, D., Borga, M., Merz, R., Blöschl, G., and Carton, A.: Controls on event runoff coefficients in the eastern Italian Alps, J. Hydrol., 375, 312-325, 2009.

Padilla, A. and Pulido-Bosch, A.: Study of hydrographs of karstic aquifers by means of correlation and cross-spectral analysis, J. Hydrol., 168, 73-89, 1995.

Penna, D., Tromp-van Meerveld, H. J., Gobbi, A., Borga, M., and Dalla Fontana, G.: The influence of soil moisture on threshold runoff generation processes in an alpine headwater catchment, Hydrol. Earth Syst. Sci., 15, 689-702, doi:10.5194/hess-15-689-2011, 2011.

Peters, E., Freer, J., and Aulenbach, B. T.: Hydrological dynamics of the Panola Mountain Research Watershed, Georgia, Ground Water, 41, 973-988, 2003.

Pfister, L., Iffly, J.F., Hoffmann, L., and Humbert, J.: Use of regionalized stormflow coefficients with a view to hydroclimatological hazard mapping, Hydrolog. Sci. J., 43, 479-491, 2002.

Pinder, G. F. and Jones, J. F.: Determination of the groundwater component of peak discharge from the chemistry of total runoff, Water Resour. Res., 5, 438-445, 1969.

Price, J.: Soil moisture, water tension, and water table relationships in a managed cutover bog, J. Hydrol., 202, 21-32, 1997.

Rodriguez-Blanco, M. L., Taboada-Castro, M. M., and Taboada-Castro, M. T.: Rainfall-runoff response and event-based runoff coefficients in a humid area (northwest Spain), Hydrolog. Sci. J., 57, 445-459, 2012.
Schumann, S., Schmalz, B., Meesenburg, H., and Schröder, U. (Eds.): Status and Perspectives of Hydrology in Small Basins. Results of the International Workshop in Goslar-Hahnenklee, 2009 and Inventory of Small Hydrological Research Basins, IHP/HWRP-Berichte 10, available at: http://www.euro-friend. de, last access: 25 September 2012, Koblenz, Germany, 2010.

Sklash, M. G. and Farvolden, R. N.: The role of groundwater in storm runoff, J. Hydrol., 43, 45-65, 1979.

Stewart, M. K. and Fahey, B. D.: Runoff generating processes in adjacent tussock grassland and pine plantation catchments as indicated by mean transit time estimation using tritium, Hydrol. Earth Syst. Sci., 14, 1021-1032, doi:10.5194/hess-14-1021-2010, 2010.

Tromp-van Meerveld, H. J. and McDonnell, J. J.: Comment to "Spatial correlation of soil moisture in small catchments and its relationship to dominant spatial hydrological processes, J. Hydrol., 286, 113-134”, J. Hydrol., 303, 307-312, 2005.

Western, A. W. and Grayson, R. B.: The Tarrawarra data set: soil moisture patterns, soil characteristics and hydrological flux measurements, Water Resour. Res., 34, 2765-2768, 1998.

Wetzel, K. F.: Runoff production processes in small alpine catchments within the unconsolidated Pleistocene sediments of the Lainbach area (Upper Bavaria), Hydrol. Process. 17, 2463-2483, 2003.

Zabaleta, A.: Análisis de la respuesta hidrosedimentaria en pequeñas cuencas de Gipuzkoa. PhD Thesis, Editorial Service of the University of the Basque Country, 252 pp., 2008.

Zabaleta, A., Martínez, M., Uriarte, J. A., and Antigüedad, I.: Factors controlling suspended sediment yield during runoff events in small headwater catchments of the Basque Country, Catena, 71, 179-190, 2007.

Zabaleta, A., Uriarte, J. A., and Antigüedad, I.: Streamflow response during rainfall events in a small forested catchment (Basque Country), in: Status and Perspectives of Hydrology in Small Basins, IAHS-AISH P., 336, 125-130, 2010.

Zehe, E., Graeff, T., Morgner, M., Bauer, A., and Bronstert, A.: Plot and field scale soil moisture dynamics and subsurface wetness control on runoff generation in a headwater in the Ore Mountains, Hydrol. Earth Syst. Sci., 14, 873-889, doi:10.5194/hess-14-873-2010, 2010.

Zhang, B., Tang, J. L., Gao, Ch., and Zepp, H.: Subsurface lateral flow from hillslope and its contribution to nitrate loading in streams through an agricultural catchment during subtropical rainstorm events, Hydrol. Earth Syst. Sci., 15, 3153-3170, doi:10.5194/hess-15-3153-2011, 2011. 